Article

\title{
Leadership Styles and War and Peace Policies in the Spanish-Basque Conflict: A Discourse Analysis of José María Aznar and José Luis Rodríguez Zapatero
}

\author{
Adrián Tarín Sanz ${ }^{1, *}$ and José Manuel Rivas Otero ${ }^{2}$ \\ 1 School of Social Communication, Central University of Ecuador, Quito 170129, Ecuador \\ 2 Department of General Public Law, Universidad de Salamanca, 37007 Salamanca, Spain; jmrivas@usal.es \\ * Correspondence: artarin@uce.edu.ec
}

Received: 5 March 2018; Accepted: 13 April 2018; Published: 17 April 2018

\begin{abstract}
The purpose of this paper is to establish possible links between leadership styles and war and peace policies in the Spanish-Basque conflict. To this end, an analysis was performed of the styles of two Spanish premiers, José María Aznar (1996-2004) and José Luis Rodríguez Zapatero (2004-2011), both of whom were involved in the same conflict with similar peace policies. The structure of the paper is as follows: an overview of the literature on leadership styles in armed conflict situations and the construction of a theoretical framework; a review of the historical and biographical context; a description of the interview content analysis methodology for measuring leadership styles; a classification of Aznar and Zapatero on the basis of their leadership styles and a comparative analysis of their policies and those enforced by other leaders in a context of internal armed conflict; and the conclusions.
\end{abstract}

Keywords: leadership style; conflict resolution; content analysis; Basque conflict; Spain

\section{Introduction}

Leadership is one of most important topics in the social sciences. Although American political science has never abandoned leadership studies, in recent years there has been a general resurgence of publications in this regard, because contemporary politics, heavily influenced by the media, focuses increasingly more on leaders and less on political parties (Blondel and Thiébault 2010; Helms 2012), even in parliamentary political regimes (McAllister 2007). Likewise, the mass media have tended to put the spotlight on the performance of leaders regarding war and peace issues or foreign affairs because the options are clearer and more easily understood by the voters (McAllister 2007).

Some works on international relations and social psychology in the interdisciplinary field of political psychology relate leadership to war and peace policies in turbulent and critical contexts (Korzenny and Ting-Toomey 1990; Burke and Greenstein 1991; Byman and Pollack 2001; Conway et al. 2001, 2003; Hermann 2003; Mares and Palmer 2012). This literature considers individual factors such as leadership (Byman and Pollack 2001), thus contributing to supplement conflict resolution studies focusing on structural variables.

The personalization of politics is a growing phenomenon in parliamentary democracies. In Spain, since the democratic transition in 1975, this has enhanced the role of the premier in the institutional structure, giving rise to the "presidentialization" of the political regime (Picarella 2009). This tendency was consolidated during José María Aznar's two terms in office, although it diminished somewhat during José Luis Rodríguez Zapatero's first premiership (Picarella 2009). Even though both premiers implemented war policies to confront Euskadi Ta Askatasuna (ETA), they also explored other more peaceful means of resolving the conflict. While Aznar toyed with the possibility of accepting the 
truce declared by ETA in 1998, Zapatero's rise to power led to a discursive turn with respect to war and peace policies, his government even engaging in peace talks with the terrorist group (Field 2009; Powell 2009). However, there are no recent studies that specifically gauge the effect of their leadership styles on the policies that they implemented in the Basque conflict.

The objective of this study is therefore to establish links between leadership styles and war and peace policies in the Basque conflict. To this end, a comparative analysis was performed of the leadership styles of Aznar and Zapatero and their war and peace policies. The initial hypothesis is that the leadership style affects these types of policies in turbulent contexts. It will be argued that, against the common belief, Aznar and Zapatero opted for similar war and peace policies in the Basque conflict and although they had different leadership styles, neither of them had a style that was conducive to its peaceful resolution.

The structure of the paper is as follows. Firstly, we will examine the literature on leadership styles and decision-making in turbulent contexts, before defining a theoretical framework. Then, after a review of the historical-biographical context, we will describe the content analysis methodology used here. Following this, we will classify Aznar and Zapatero in terms of their leadership styles and perform a comparative analysis of the policies implemented by them in the Basque conflict. Lastly we will present our conclusions.

\section{Leadership Styles and War and Peace Policies in Turbulent Contexts}

Leadership is central to political analysis because leaders play an important role in political processes, but its definition is complex and elusive (Elcock 2001). This paper focuses on leadership styles by applying personal traits and behavioral approaches to the study of leadership. A political leader is an individual who has the authority to allocate resources, determine the objectives of a political regime, and affect its policies (Katz 1973). Personal traits are the particular features or characteristics of an individual's personality: gender, age, birthplace, educational and social background, experience, abilities and skills, motivation, or beliefs and values.

The consideration of leadership as a style means defining it as a set of personal traits assessed by discourse analysis, which "has an obvious connection with the behavior" of the leader in question (Hermann and Milburn 1977, p. 2). A leadership style consists of manifest personal traits that respond to three dilemmas that affect the political behavior and decision-making of a leader: learning how to maintain political control; delegating responsibilities or assuming the leading role; and how to shape the political agenda, motivated by problems and/or relations (Hermann 2003).

Studies of leadership styles and decision-making have proliferated more in the field of social psychology. In the 1930s, Lewin et al. (1939) developed a controlled experiment to test the effects of different leadership styles on the behavior of individuals in groups. Two decades later, Lasswell (1963) produced two profiles based on an analysis of the medical records of political leaders: the administrator who values continuous activity and "focuses on abstract objects"; and the agitator who is highly narcissistic and "allocates a high value to the public response" (Lasswell 1963, pp. 250-51).

Over the past decades, many studies of leadership styles, mainly theoretical in nature, have been conducted. The research performed by Burns (2010) has had a greater scientific impact than others since it was first published in 1978. He distinguishes between two leadership styles: transactional, based on a relationship of economic, political, or symbolic exchange with the leader's followers; and transformational, based on the identification with the leader's followers and the commitment of both to achieving a common goal. The former is more common in stable contexts, while the latter proliferates in those of political change. Moreover, MacGregor Burns considers that the specialization of the decision-making process is the essence of executive function. To his mind, executive leaders are given greater freedom to make such decisions in military or armed conflict contexts, in post-revolutionary situations, or for government reform (Burns 2010).

By the same token, in his study of presidential power in the Neustadt (1990) observes that the status of commander-in-chief of the armed forces allows the president to make defense 
budget proposals and military appointments and to declare war and sue for peace. ${ }^{1}$ Furthermore, Arnson (1999) and Butler (2009) mention the important role played by leaders in the Latin American and Middle Eastern peace processes.

Notwithstanding this, few studies in the field of political science have established a link between leadership styles and decision-making in turbulent contexts. In contrast, authors specializing in international relations and social psychology have published numerous academic papers on this topic. Waltz (1959) was the first to propose the analysis of the personality and behavior of leaders as a valid method for explaining state behavior, but he excluded them because he considered that explanations of this type were not parsimonious enough.

Daniel Byman and Kenneth Pollack (Byman and Pollack 2001) and David R. Mares and David Scott Palmer (Mares and Palmer 2012) have continued to approach this issue from the perspective of international relations. Byman and Pollack (2001) examine the impact of individual leaders on state behavior by examining several historical examples and conclude that individual actors play a central role in shaping a state's foreign policy, including wars, alliances and peace processes, while in the framework of the conflict between Peru and Ecuador (1995-1998), Mares and Palmer (2012) identify several leadership styles that, along with other structural and institutional factors, help to explain the making of certain types of decisions in a context of armed conflict, such as war policies. Their book corroborates one of the hypotheses suggested by Byman and Pollack (2001), according to which leaders who are more willing to take risks are more prone to causing or prolonging wars.

In the field of social psychology, the authors discuss the assessment the personality in politics. These studies observe that certain aspects of a leader's personality can influence the decision-making process, especially as regards foreign policy (Kernberg 1999). A good example is the book by Greenstein (2009) in which he analyzes the leadership styles of American presidents from Franklin E. Roosevelt to Barack Obama, considering different personal traits such as communication skills, organizational capacity, political ability, cognitive style and emotional intelligence.

Aubrey Immelman (2003) distinguishes three conceptual and methodological approaches: content analysis, expert ratings, and psychodiagnostic analysis of biographical data. The measurement of leadership styles to analyze its impact on political decisions has been based, first and foremost, on content analysis. Content analysis "remains the dominant approach to indirect personality assessment and is widely acknowledged in political psychology as a reliable data-analytic method" (Immelman 2003, p. 613).

For their part, David Winter and Margaret Hermann have constructed leadership profiles using linguistic text analysis (LTA), a content analysis technique. Winter and his team have evaluated the motivations, cognitions and personality traits of George Bush and Mikhail Gorbachev by comparing the assessment of their leadership styles—-possessed attributes—with the opinions of the media and the public at large-perceived attributes (Winter 1991). On the other hand, Hermann (2003) has identified three personality dimensions: sensitivity to political constraints; openness to information; and motivation for action. They all include personal traits with which the author constructs different leadership styles that have an impact on the decision-making and government policies of leaders.

Some leadership style studies only consider one of the previous dimensions proposed by Hermann, namely, a political leader's openness to information. For their part, John Burke and Fred Greenstein (Burke and Greenstein 1991) compare the Vietnam War decisions of Eisenhower and Johnson and observe how the former, more willing to listen to his advisors, adopted a position against the war, whereas the latter, less willing to take advice, launched a military intervention that would lead to one of the greatest military defeats in American history.

1 The President shares this last function with Congress: the former can veto the decision of Congress, but the latter can overrule it with a two-thirds majority. 
Conceptual or integrative complexity is a personal trait forming part of the dimension called "openness to information". This psychological construct, studied by Conway et al. (2001, 2003, 2011), indicates the extent to which individuals discern different perspectives on a specific problem-differentiation - and the extent to which these perspectives are integrated into a coherent framework-integration. ${ }^{2}$ In turbulent contexts (crisis, conflict, war, etc.), leaders with a low integrative complexity adopt more inflexible stances, thus making them more likely to trigger conflicts. In contrast, leaders with a high integrative complexity are more flexible and cooperative and thus more inclined to consensus.

Similarly, the studies conducted by Dyson $(2006,2009 a, 2009 b, 2016)$ inquire into the national and international politics of the British premiers Margaret Thatcher, Tony Blair and Gordon Brown. Focusing on their personal traits, specifically their cognitive ability, this author argues that leaders with a low degree of conceptual complexity, namely a worldview based on dichotomies (good/bad, friend/foe, black/white, etc.), have problems in processing information and with decision-making. ${ }^{3}$

Motivation is another leadership style dimension that is usually analyzed. The works that highlight motivational traits claim that leaders with a high group identity or very distrustful of other groups have a belief system that undermines their ability of critical reflection and makes them more willing to take risks and provoke conflicts (Walker 1990; Byman and Pollack 2001).

In contrast, those leaders with a tendency to resolve common problems are more inclined to dialogue and negotiation (Hermann 2003). Some authors (George 1969; Walker 1977, 1990, 2011; Schafer and Walker 2006) adopt the operational code approach to explain the relationship between leaders' motivational beliefs and their policy-making behavior. Others academics, led by Winter (1973, 1991, 2003a, 2003b), focus on personal traits of the leaders using a conceptual framework derived from the Thematic Apperception Test (TAT). Winter $(1973,2003 \mathrm{~b})$ distinguish three dimensions of motivated behavior: achievement, affiliation and power; the achievement motivations are linked to the need to act according to the consequences, the affiliation motivations are related with the personal relationships, and the power motivations is associated to the social prestige and the impulse to take risks. This classification is applied to the business executives (Winter 1991), political executive leaders (Winter 1973, 2003a), and opposition leaders (Winter 2011).

\section{Historical-Biographical Context: Aznar, Zapatero and the Basque Conflict}

Aznar (People's Party (PP)), the Spanish prime minister from 1996 to 2004, was a fundamental figure in the Basque conflict. His term in office can be divided into at least two stages: the first from the beginning of his premiership to the 1998-1999 truce, a period in which he apparently took a more moderate line and was more open to a political solution to the conflict; and the second, from the failure of the overtures of peace to the end of his second term in office, in which he shifted towards an approach based on public order and the strict enforcement of the (new) law. The transition from one state to another was progressive and at times ambiguous.

In 1996, nearly 30 years after the advent of ETA, Aznar became the fourth Spanish prime minister-and the first who was openly conservative-since the death of the dictator Francisco Franco (Keating 1996). His electoral victory was partly due to the demerits of his main rival the Spanish Socialist Worker's Party (PSOE) 4 and partly to having won "national popularity by pledging to end ETA violence, and to eradicate ETA and its networks," after having been attacked by the Basque terrorist group the year before. In response, "the Basque movement took yet another turn

2 This personal trait was theorized by Schroder (1971) and studied by Levi and Tetlock (1980) in order to explain the decision-making of political leaders during the Second World War.

3 For example, Tony Blair's leadership style (proactive, self-confident, sanctimonious and high-hand when making decisions) was successful as regards British foreign policy in Kosovo and Sierra Leone, but a failure in Iraq (Dyson 2009b, p. 7).

4 According to Amodia (1996, p. 314), the PSOE's public image had been damaged by different cases of corruption affecting the government and other state institutions, as well as by the "dirty war" against ETA. Likewise, "the right-wing forces, represented by the Popular Party (PP) and led since 1989 by Jose Maria Aznar, had been moving in the opposite direction." 
and PP politicians became the preferred targets of ETA along with military and police personnel" (Linstroth 2002, pp. 207-8). However, since his party did not have an absolute majority in Parliament, he was obliged to look for allies among the other parliamentary groups and, in an "ironic turn" (Keating 1996), ultimately struck a deal with the Basque, Catalan and Canaries nationalist parties. According to political analysts at the time, this could have been one of the reasons why Aznar had to moderate his tone vis-à-vis the country's conservative peripheral nationalism during his first term in office.

Even so, due to Aznar's personal image of staunch champion of the victims of terrorism, the PP managed to convince the PSOE to adopt a more conservative stance. Thus, the

leadership of the Basque section of the PSOE $(\ldots)$ to assume the postulates of the $\mathrm{PP}$, which sought a new non-nationalist majority in the autonomous executive on the basis of a program founded on respect for the Statute and the Spanish Constitution (Ibarra and Ahedo 2004, p. 364).

That the Spanish Constitution was a "red line" that could not be crossed, even in the hypothetical context of talks with ETA, was constantly repeated by Aznar and one of his main identity traits, thus demonstrating his preference for a "political solution" (Linstroth 2002). In point of fact, shortly after coming to power this strategy began to pay off in the media: in July 1997 the Civil Guard freed the prison officer José Ortega Lara, one of the symbols of the victims of terrorism, who had been kidnapped by ETA and held captive for nearly 18 months. Nonetheless, a few days later, ETA hit back with another kidnapping. On 10 July, the Basque terror group held the PP councilor Miguel Ángel Blanco for 48 hours, while it demanded that the Spanish government regroup ETA prisoners in Basque jails as a condition for his liberation. Aznar refused to comply with their demands and the armed organization promptly executed the councilor.

The murder of Blanco marked a turning point insofar as it led to the birth of the "Spirit of Ermua" movement, "the anti-terrorist solidarity expressed by all of Spain's democratic parties amidst the massive popular repudiation of ETA" (Gillespie 2000, p. 113). For the first time, this spirit led to a genuine rapport between the so-called "constitutionalist parties" (PP and PSOE), the Basque Nationalist Party (PNV) and broad swathes of civil society opposed to the violence of the terror group, which hitherto had had their political differences as regards the conflict. However, the movement was "swiftly exploited by the Popular Party, which extended its criticisms to include not only radical nationalism, but nationalism as a whole" (Ibarra and Ahedo 2004, p. 364).

Perhaps influenced by this massive movement repudiating its actions, ETA declared a truce in 1998 which was to peter out a year later. ${ }^{5}$ Yet this setback did not affect Aznar's electoral prospects, but quite the opposite for he managed to achieve an absolute majority in Parliament in the 2000 general elections, while obtaining the best result in the Basque Country in the party's history. ${ }^{6}$ During his second term in office, his management of the conflict became more inflexible: "After gaining an absolute majority in Spanish national parliamentary elections in 2000, however, the PP veered to the Spanish nationalist pole, dragging the Socialists in its wake" (Keating and Bray 2006, p. 354). At least three events occurring in the following parliamentary term bore this out: the signing of the antiterrorism agreement; the PP's frontal opposition to the Ibarretxe Plan; and the inclusion of ETA in the American "war on terror".

The first, officially called the "Agreement for Freedom and against Terrorism", was a document drawn up in collaboration with the PSOE by virtue of which the main opposition party agreed to lend the Government its unconditional support as regards counterterrorism measures. This agreement alienated the Basque nationalist parties, which in its preamble were accused of having been closer

5 The ins and outs of this truce and those declared during Zapatero's premierships are covered in the fifth section of this paper. 6 According to official data provided by the Ministry for Home Affairs, the PP obtained $28.26 \%$ of the votes in the Basque Country, 10 percentage points more than in previous elections. 
to ETA than to the "constitutionalist parties" during the previous truce. ${ }^{7}$ It undermined the unity between nationalists and constitutionalists forged after the Spirit of Ermua-it should be recalled that the Government's new absolute majority meant that the support of the PNV in Parliament was now unnecessary - and opened the possibility of introducing different legal reforms that stepped up the judicialization of the conflict, such as the illegalization of the Basque left-wing pro-independence party (Caminos-Marcet et al. 2013).

The second - the Ibarretxe plan-which was launched by the PNV in September 2002, involved amending the Statute of Autonomy of the Basque Country to increase the region's self-rule. "Although not calling for secession from Spain, it challenged the basis of Spanish state sovereignty as enshrined in the constitution of 1978 by claiming the right for residents of Euskadi to vote on their relationship with the Spanish state" (Keating and Bray 2006, p. 348). The plan was strongly opposed by the PP and the PSOE-in line with the antiterrorism agreement-and was ultimately rejected in Parliament in 2005, when Aznar was no longer Prime Minister. ${ }^{8}$

The third-the 11-S attacks and the wars in Afghanistan and Iraq-gave Aznar the extra (international) justification that he needed to apply stricter counterterrorism measures. The support of the United States, the coinciding Spanish EU presidency and a heightened awareness of terrorism provoked by the attacks enabled the Spanish government to tighten up the country's legislation on political violence, without practically any opposition (Zernova 2017). In parallel, the Spanish press also spread false rumors about the links between al-Qaida and ETA, which the Basque organization denied in several communiques (Linstroth 2002). A few years later, following the train bombings in Madrid on 11 March 2004 (11-M), the PP (and the right-wing press) would unearth these links.

During the four days between the bombings and the 2004 general elections, the Aznar government defended the thesis that ETA was to blame, despite the fact that different political sources and national and international media released information that pointed more to a jihadist attack motivated by the controversial Spanish support for the Iraq War. ${ }^{9}$ The ensuing clash between those supporting the official version and those the alternative one, encouraged by the Government and opposition parties, respectively, ${ }^{10}$ led to Zapatero's unexpected victory in the general elections (Lago and Montero 2006), even though there was already widespread dissatisfaction with the government policies of the last parliamentary term, which also had an impact on the results (Fishman 2007).

The polarization PP-PSOE brought about by the attacks went from bad to worse during the parliamentary term 2004-2008, above all after the passing of laws providing redress for the victims of the Spanish Civil War and the Franco dictatorship; the legalization of gay marriage; the clash between religious education and the newly created citizenship education module; and the negotiations with ETA during 2005-2006 (Field 2009).

The Government's negotiations with the terrorist organization were lambasted by the Association of Victims of Terrorism (AVT) (Chari 2008) and by the PP (Sánchez-Cuenca 2009), interpreting them as a definitive break with the antiterrorism agreement. Due to the opposition's hostility, the peace process came, as on previous occasions, to a dramatic end: in December 2006, ETA detonated a car bomb in the carpark of Barajas-Adolfo Suárez Airport (Madrid), killing two people. A year later, during the 2008 election campaign in which the PP (critically) placed the negotiations between the Zapatero government and ETA at the center of the debate, the terrorists killed the PSOE councilor

7 Literally, the agreement established that "ETA's return to terrorist violence, after the temporary truce announced in September 1998, has dramatically highlighted the situation in the Basque Country. This has also evinced the failure of the strategy promoted by the PNV and EA, which abandoned the Ajuria Enea Agreement in order to put a political price on an end to the violence, in concert with ETA and EH. The price to be paid was the imposition of self-determination to achieve the independence of the Basque Country" (Agreement for Freedom and against Terrorism 2000, 8 December).

8 For a comprehensive analysis of the Ibarretxe Plan (2001-2005) and the political context, see Pallarés et al. (2006).

9 However, in what is surely the best study in this regard Reinares (2014) confirms the jihadist hypothesis, although he tempers the belief that is was (exclusively) due to Spanish invention in Iraq.

10 For a framework analysis of the political and media discourses at the time, see Canel (2012). 
Isaías Carrasco. "All parties immediately suspended the rest of the electoral campaign in mourning" (Chari 2008), but the climate of confrontation prior to this prevented something similar to the Spirit of Ermua from being repeated.

Returning to the elections, the aforementioned polarization made the vast majority of voters cast their ballot for the PSOE (43.87\%) and the PP (39.94\%), with a consequent drop in support for the country's minority parties. ${ }^{11}$ In spite of neither having an absolute majority in Parliament nor government alliances in place, Zapatero was sworn in as prime minister with a simple majority of 183 votes on 17 April 2004. At the end of the year, the violence of ETA peaked: four deaths and one attack against the headquarters of the Basque television broadcasting company.

The rest of the parliamentary term was marked by the global economic crisis and, with regard to the Basque conflict, by the first autonomous government led by the "constitutionalist bloc". The PNV - alone or in coalition with other parties — had been in power since the end of the dictatorship. From 1999 to 2009, Juan José Ibarretxe was lehendakari (prime minister) of the Basque Country, lending his name to the plan for institutional reform to achieve greater self-rule. Nonetheless,

his reluctance to break ties with ETA backed political supporters, his erratic behavior towards the victims of ETA (giving similar weight to ETA's victims and the hardship experienced by members of ETA in prison), and his attempts to hold a referendum for a sort of confederation of the Basque Country with Spain (openly non-constitutional) were likewise resented by many in the Basque Country and in the rest of Spain (De la Calle and Sánchez-Cuenca 2009, p. 206).

To the discontent with the PNV must be added the "constitutionalist" victory, the illegalization of the Basque left-wing pro-independence party and the regional exceptionality that gives preference to the center-periphery axis over the left-right one (Linstroth 2002). ${ }^{12}$ "As a consequence, and due to a pact between the socialists and the conservative PP, in May 2009, the socialist leader Patxi Lopez was elected new lehendakari" (Mees 2015, p. 55).

A year after, on 5 September 2010, ETA announced a new ceasefire. Since then and until the "definitive end to the violence", declared in October 2011, the terrorist organization publically enumerated the steps that it was taking towards its disarmament, under the skeptical eye of the Spanish government. Exactly a month later, on 20 November 2011, the PSOE lost the elections, thus giving rise to a new cycle of PP governments.

\section{Method: Assessing Leadership Styles by Content Analysis}

The measurement of leadership styles is performed by assessing certain personal traits of political leaders. To this end, different techniques can be used. ${ }^{13}$ One of these, content analysis, which can be quantitative or qualitative, is a research technique for the objective and systematic description of the manifest content of communication (Berelson 1952). Qualitative content analysis involves a detailed examination of a text, but does not include a quantification process (Hermann and Milburn 1977), while quantitative analysis directly accesses the meaning of the different segments making up a text, without considering the textual material itself, and is performed in two stages. First, a set of categories

11 For more detailed information on voting behavior in the 2008 elections, see Torcal and Lago (2008).

12 Leonisio (2012) refers to a firm reality in Catalonia and the Basque Country: at key junctures, the antagonism is more cultural-national than ideological-economic. Thus, in the Basque Country the conservative PNV has governed in coalition with progressive pro-independence parties, rather than with the right-wing constitutionalists (and vice versa). Even so, in 2012 the Basque federation of the PSOE was unable to remain in power due to Zapatero's unsatisfactory management of the economic crisis. Consequently, the PNV regained the lehendakaritza thanks to the transfer of progressive votes, in which might have been the first elections in which the limits between both axes (national and economic) became blurred (Gómez-Fortes and Cabeza-Pérez 2013).

13 Hermann and Milburn (1977) enumerate some of them: questionnaires, interviews, participatory observation, content analysis, biographical statistics and simulation. 
(generally words or sets of words, but also phrases, partial phrases and complete texts) is defined, and then the times that these appear in the analyzed text are identified and counted (Lebart et al. 2000; Alonso et al. 2012).

This process must be reliable and replicable; if someone else uses the same rules and the same material, a similar result should be obtained (Alonso et al. 2012). Content analysis is generally designed so that expert raters can apply it with high reliability by use of a codification manual, and some examples, and training procedures (Winter 2003b, p. 114). However, it should be noted that content analysis presents some validity problems as "the logic of psychological inferences about communicators engaging in persuasive communication" (Holsti 1977, pp. 133-34), uncertainty about the authorship of the speeches, and problems of coding and data analysis (Holsti 1977; Immelman 2003).

Specifically, LTA - a quantitative content analysis technique measuring leadership styles based on certain personal traits, which has been successful in terms of validity-was employed in this study. ${ }^{14}$ LTA has four phases: selecting the material; splitting up the text into coding units; creating a classification system with dimensions and categories; and quantifying and presenting the results.

This analytical technique was applied here to the content of acquired interviews. Unlike research interviews, they are conducted by third-party interviewers, primarily by media corporations. In these types of interviews, neither do researchers control the topics to be addressed, although they usually have the advantage of possessing more material, nor more importantly do they are more spontaneous than speeches and depend on the cooperation of the political leader (Hermann and Milburn 1977). In content analysis, moreover, the rules for the amount of material to be selected depend on the research questions (Alonso et al. 2012, p. 16).

The acquired interviews making up the study sample were retrieved from a database that includes 335 interviews conducted with 72 international political leaders between 1979 and 2016, deriving from diverse media (newspapers, radio and television) as well as from other secondary sources (academic interviews, foundations, NGOs and websites). ${ }^{15}$ In addition to the interviews with Aznar and Zapatero, it was necessary to include those with a significant number of leaders included in the database in order to compare the average for the leaders under study with the overall averages for each category.

Coding units are linguistic elements that are quantified in each one of the categories and dimensions of content analysis. The LTA technique employed here counts words or groups of words in each category, while taking into account their meaning in the text, sentence or partial sentence. Using Hermann (2003) as a reference, the coding system was structured around five categories grouped into two dimensions.

14 According to Hermann (2003), when comparing leaders' profiles obtained by this technique in some of his papers with profiles made by journalists and former government officials who had interacted with and observed these same leaders, a high correlation (0.84) was obtained. By the same token, in Rivas and Tarin (2017) the authors' word count replicated those of three independent researchers studying the leadership styles of Maskhadov and Umarov, obtaining high correlations of between 0.79 and 1.00 .

15 The database includes interviews with leaders from all states (even unrecognized ones) and autonomous regions, with or without internal armed conflict: Gerry Adams (Northern Ireland); Mahmoud Ahmadinejad (Iran); Patricio Aylwin and Sebastián Piñera (Chile); Virgilio Barco, Jaime Bateman, Belisario Betancur, Alfonso Cano, Álvaro Fayad, César Gaviria, Timoleón Jiménez, Iván Márquez, Manuel Marulanda, Antonio Navarro Wolf, Tanja Nijmeijer, Andrés Pastrana, Manuel Pérez, Gustavo Petro, Carlos Pizarro, Nicolás Rodríguez, Ernesto Samper, Juan Manuel Santos, Jesús Santrich, Julio César Turbay and Álvaro Uribe (Colombia); Shamil Basayev, Dzhokhar Dudayev, Aslan Maskhadov and Doku Umarov (ChRI-CE); Tony Blair, David Cameron and Margaret Thatcher (UK); George W. Bush, Bill Clinton and Barack Obama (USA); Che Shui-Bian and Ma Ying-Jeou (Taiwan); Andrés Manuel López Obrador (Mexico); Rafael Correa (Ecuador); Susana Díaz (Andalusia); Mauricio Funes, Tony Saca and Shafik Haldal (El Salvador); Muammar Gaddafi (Libya); Mikhail Gorbachev (USSR); Hu Jintao and Xi Jinping (PRC); Juan José Ibarretxe and Arnaldo Otegi (Basque Country); José María Aznar, Pablo Iglesias, Mariano Rajoy, Albert Rivera and José Luis Rodríguez Zapatero (Spain); Lech Kaczynski (Poland); Ramzan Kadyrov (Chechnya); Salva Kiir Mayardit (South Sudan); Luiz Inácio Lula da Silva and Dilma Rousseff (Brazil); Artur Mas and Jordi Pujol (Catalonia); Thabo Mbeki and Jacob Zuma (South Africa); José Mújica (Uruguay); Vladimir Putin and Boris Yeltsin (Russia); Alex Salmond (Scotland); Arnold Schwarzenegger (California); Manmohan Singh (India); Horst Seehofer (Bavaria); and Hashim Thaçi (Kosovo). 
The first dimension, which defines the leader's openness to information, consists of two coding unit categories (for words or groups of words), i.e., the leader's conceptual complexity and his or her degree of self-confidence. Conceptual complexity indicates the extent to which individuals classify objects and ideas and react to external stimuli: those who lack this ability classify everything by polarizing parameters and are less flexible. Lastly, self-confidence represents the idea that individuals have about their ability to cope properly and interact with objects and people in their environment.

The second dimension, which measures the leader's motivation type, contains three categories (for words or groups of words): the leader's tendency to solve problems, identification with certain groups and distrust of external groups. Leaders with a tendency to solve problems exert their leadership to meet specific objectives for the group, while those focusing on the group seek to maintain its cohesiveness by extolling its identities (i.e., people, religion, nation-country, region, social class, etc.) and/or by generating distrust of other external groups (i.e., empires, terrorists, infidels, other countries, etc.). ${ }^{16}$

Once the categories of the leader in question have been identified, his or her leadership style can be defined. The leadership style typology proposed by Hermann (2003) is designed for studies of foreign policy decision-making, but not of war and peace policies in armed conflict situations. Therefore, a typology was constructed in terms of the possible combinations of dimensions and categories resulting from the content analysis (Table 1).

Table 1. Dimensions, categories and leadership styles.

\begin{tabular}{lll}
\hline \multicolumn{1}{c}{ Dimensions } & \multicolumn{1}{c}{ Categories } & \multicolumn{1}{c}{ Leadership Style } \\
\hline \multirow{2}{*}{ Openness to information } & $\begin{array}{l}\text { Lack of conceptual complexity } \\
\text { Self-confidence }\end{array}$ & $\begin{array}{l}\text { Manichean } \\
\text { Self-assured }\end{array}$ \\
\hline & Lack of conceptual complexity + Self-confidence & Hermetic \\
\hline \multirow{3}{*}{ Motivation } & $\begin{array}{l}\text { Tendency to solve problems } \\
\text { Identification with groups } \\
\text { Distrust of other groups }\end{array}$ & $\begin{array}{l}\text { Troubleshooter } \\
\text { Umbrella } \\
\text { Suspicious }\end{array}$ \\
\hline & $\begin{array}{l}\text { Identification with groups + Distrust of other } \\
\text { groups }\end{array}$ & Sectarian \\
\hline None & & Administrator (without style) \\
\hline
\end{tabular}

The conceptual complexity of Manichean leaders (i.e., Margaret Thatcher and Mariano Rajoy) is below average and they perceive reality by polarizing parameters. Self-assured leaders (i.e., Bill Clinton, George W. Bush and Jacob Zuma) have strong ideological convictions and are all but unreceptive to external information (Hermann 2003, p. 18). Hermetic leaders (i.e., Tony Blair and Ernesto Samper) combine a low degree of conceptual complexity with a high self-confidence, making them less open to advice. Troubleshooter leaders (i.e., Hu Jintao, Xi Jinping and Juan Manuel Santos) are motivated by the resolution of group or political problems. The principal objective of umbrella leaders (i.e., Manuel Pérez and Hashim Thaçi) is to promote their group identity. Suspicious leaders (i.e., Álvaro Uribe and Bashar al-Assad), albeit motivated by the group, are mainly concerned about preventing other groups from interfering in their affairs. Finally, sectarian leaders (i.e., Doku Umarov and Shamil

16 In addition to the aforementioned dimensions and categories, in order to assess leadership styles Hermann (2003) uses another dimension-the leader's reaction to his or her environment's limitations-which consists of two categories: his or her control belief and the need for power and influence. In this study, these categories are not considered for several reasons. Firstly, unlike the other four dimensions, they are treated as phrases or partly completed phrases rather than words or groups of words, which complicates their objective measurement and integration with other categories for classifying leadership styles. Secondly, control belief is already measured in some sense in the self-confidence category. Finally, the second category excluded from the analysis is complicated to measure and it is also hard to imagine leaders lacking ambition and the need for power and influence. 
Basayev) combine appeals to group identity with the open rejection of enemy groups (Hermann 2003, pp. 25-29).

All these leadership styles are compatible in a single leader, except the administrator (i.e., Manmohan Singh, David Cameron and Dilma Rousseff), which is a typology (taken from Weber's professional politician and Lasswell's administrator leader) for leaders who obtain an average or low score in all the analytical categories and therefore do not exhibit any leadership style.

In the last phase of the content analysis, the words or groups of words belonging to each category were identified (Table 2) and the number of times that they appeared in each interview counted. After quantification, the frequency with which these words or groups of words were repeated in each category in each one of the interviews was calculated and the assessment of the leaders' traits were determined using the following formula: leader $\bar{X}-$ total $\bar{X}>\sigma$; that is, leaders fell into a category when the difference between their average percentage and the overall average percentage was greater than the standard deviation within the category in question. The criteria proposed by Hermann $(2003$, p. 32) have proven to be reliable and have been used successfully in various academic works to assess leadership styles (Dyson 2009b; Hermann and Sakiev 2011; Keller and Foster 2016; Rivas and Tarín 2017).

Table 2. Content analysis: dimensions, categories and coding units.

\begin{tabular}{|c|c|c|}
\hline Dimensions & Categories & Coding Units \\
\hline \multirow[t]{2}{*}{ Openness to information } & Lack of conceptual complexity & $\begin{array}{l}\text { Words: Absolute, absolutely, definitely, doubt(less), } \\
\text { certainly, full, fully, clear, clearly, obvious, obviously, } \\
\text { evident, completely, quite, surely, total, totally, } \\
\text { irreversible, irrevocable, final, finally, at all, I have no } \\
\text { doubt, no doubt, without hesitation, of course, I am } \\
\text { sure, no turning back. }\end{array}$ \\
\hline & Self-confidence & $\begin{array}{l}\text { Words: I, my, myself, me, mine, confidence, } \\
\text { conviction, I have been, a server, other } \\
\text { self-references. }\end{array}$ \\
\hline \multirow{3}{*}{ Motivation } & Tendency to solve problems & $\begin{array}{l}\text { Words (verb forms): to advance, to solve, to } \\
\text { overcome, to resolve, to restore, to restructure, to } \\
\text { strengthen, to negotiate, to defeat, to stop, to end, to } \\
\text { finish, to terminate, to reduce, to prevent, to appeal, } \\
\text { to accomplish, to achieve, to reach (goals), to } \\
\text { transform, to propose. } \\
\text { Words: negotiation, achievement, progress, success, } \\
\text { goal, challenge, proposal, future. }\end{array}$ \\
\hline & Identification with groups & $\begin{array}{l}\text { Positive words: people, nation, country, homeland, } \\
\text { patriot, independence, identity, self-determination, } \\
\text { sovereign, (supra)region, poor, humble, grassroots, } \\
\text { religious group, God, Gospel, Bible, Jesus, Islam, } \\
\text { Muslim, Allah, Koran, Sharia, Muhammad, social } \\
\text { class (no middle). }\end{array}$ \\
\hline & Distrust of other groups & $\begin{array}{l}\text { Words: enemy, terror, terrorist, terrorism, subversive, } \\
\text { rebels, traitors, bandits, separatists, extremism, } \\
\text { radicalism, totalitarianism, oligarchy, caste, criminal } \\
\text { group, putsch, coup d'état, conspiracy, apostates, } \\
\text { infidels (kafirs), murder, torture, genocide, massacre, } \\
\text { extermination, dictatorship, authoritarian, slaughter, } \\
\text { domination, destruction, bombs, bombing, } \\
\text { disappearance, repression, forced displacement, } \\
\text { kidnapping, threat, external threat, Islamism, } \\
\text { fundamentalism, Wahhabism, al-Qaeda, ETA, } \\
\text { communism, Chavism, fascism, Nazism, } \\
\text { imperialism, empire, imperial, superpower, WMD, } \\
\text { chemical/nuclear weapons, occupation, occupants, } \\
\text { invaders, colonial and other derogatory terms. }\end{array}$ \\
\hline
\end{tabular}


To ensure the reliability of the method, a codification manual containing the rules and standards for replicating the results was drawn up (Table 3). The word count has been replicated by three independent researchers: the first obtained correlations of 0.96 (Aznar) and 0.93 (Zapatero); the second, 0.90 (Aznar) and 0.82 (Zapatero); and the third, 0.93 (Aznar) and 0.81 (Zapatero). ${ }^{17}$

Table 3. Rules and regulations.

\begin{tabular}{|c|c|}
\hline Rules & Regulations \\
\hline $\begin{array}{l}\text { 1. Applicable to any type of executive leader, } \\
\text { belonging to the opposition or insurgent, in any } \\
\text { context or historical period. }\end{array}$ & $\begin{array}{l}\text { 1. Three or more interviews with each leader, whose } \\
\text { answers total any number between } 6000 \text { and } \\
12,000 \text { words, must be included. }\end{array}$ \\
\hline $\begin{array}{l}\text { 2. All or only some of the characteristics proposed as } \\
\text { analytical categories can be evaluated. }\end{array}$ & 2. Interviews must be in $\mathrm{Q} \& \mathrm{~A}$ format. \\
\hline $\begin{array}{l}\text { 3. Does not allow any other material than the } \\
\text { interview; acquired interviews are analyzed; but } \\
\text { research interviews can also be used. }\end{array}$ & 3. Interviews must have three or more Q\&As. \\
\hline $\begin{array}{l}\text { 4. The proposed leadership styles in terms of the } \\
\text { analytical categories are not exclusively limited to } \\
\text { armed conflict situations. }\end{array}$ & $\begin{array}{l}\text { 4. The interviews employed to evaluate a leader } \\
\text { cannot come from the same media outlet, i.e., at least } \\
\text { one of them must be from a different one. }\end{array}$ \\
\hline $\begin{array}{l}\text { 5. The sample is not representative; a high number of } \\
\text { leaders can be included in order to obtain an overall } \\
\text { average for each category. }\end{array}$ & $\begin{array}{l}\text { 5. The word count is exclusively limited to the } \\
\text { proposed units of quantification (words or groups of } \\
\text { words). }\end{array}$ \\
\hline $\begin{array}{l}\text { 6. The type of media outlet publishing the interview } \\
\text { can serve as a control variable. }\end{array}$ & $\begin{array}{l}\text { 6. In the word count, the meaning of the words or } \\
\text { groups of words in a phrase must be borne in mind. }\end{array}$ \\
\hline $\begin{array}{l}\text { 7. Averages are calculated as percentages (\%), } \\
\text { although a different unit of measurement can be } \\
\text { applied. }\end{array}$ & $\begin{array}{l}\text { 7. Averages are calculated by taking the number of } \\
\text { words in each answer given by the leader, rather than } \\
\text { the overall number of words in the interview. }\end{array}$ \\
\hline $\begin{array}{l}\text { 8. All categories are inclusive, compatible in one } \\
\text { single leader. Each proposed category implies a } \\
\text { different leadership style. When leaders do not } \\
\text { possess any of the characteristics measured in the } \\
\text { analytical categories, they are classified as } \\
\text { administrators. }\end{array}$ & $\begin{array}{l}\text { 8. Leaders fall into an analytical category when the } \\
\text { result of the difference between their average and the } \\
\text { overall average is more than half of the standard } \\
\text { deviation of the said category (leader } \bar{X}-\text { total } \bar{X}>\sigma \text { ). }\end{array}$ \\
\hline
\end{tabular}

Source: own elaboration.

Having described the content analysis, the time has now come to take a look at the policies implemented by executive leaders in armed conflicts. There are two types of policies in this context, namely, war policies and peace policies, which differ in a number of important aspects: the former are an autonomous decision of the leader, while the latter are the result of an agreement between the parties within the framework of dialogue or a peace process (Rivas and Tarín 2017, p. 8). Albeit only the peace policies that an executive leader, as head of the government, can pursue through institutional channels without the need to reach an agreement with an insurgent or terrorist group.

Table 4 includes seven war and peace policies that executive leaders can develop in an armed conflict. Since these are two categorical variables, their order does not necessarily correspond to a greater degree of negotiation or confrontation. In order to compare styles and policies, the war and peace policies implemented by Aznar and Zapatero were identified and classified according to the leadership styles described above.

17 The following researchers took part in the reliability test: Sergio García-Rendón, Asbel Bohigues and Nicolás Miranda, members of the Area of Political Science and Administration, Department of General Public Law, University of Salamanca. 
Table 4. War and peace policies.

\begin{tabular}{ll}
\hline \multicolumn{1}{c}{ War } & \multicolumn{1}{c}{ Peace } \\
\hline Special criminal laws and national security programs & Creation of a government body for peace negotiations \\
\hline $\begin{array}{l}\text { Banning political parties linked to the enemy and } \\
\text { persecuting those in their orbit }\end{array}$ & Participation in peace talks or processes \\
\hline Collecting special taxes & Prisoner exchange or prison benefit policies \\
\hline Tactical deployment of the army and/or security forces & Amnesty \\
\hline Declaration of a state of emergency or siege & $\begin{array}{l}\text { Proposing agreements of a political, social or } \\
\text { economic nature }\end{array}$ \\
\hline Military or police operations & Halting military/police operations during a ceasefire \\
\hline Illegal and extrajudicial executions and kidnappings & $\begin{array}{l}\text { Compliance with transitional justice, reparation for } \\
\text { victims and guarantees for political participation }\end{array}$ \\
\hline
\end{tabular}

Source: own elaboration.

\section{Results and Discussion: The Leadership Styles of Aznar and Zapatero and the War and Peace Policies of Their Governments}

In this section, the results of the content analysis are presented to classify Aznar and Zapatero according to their leadership styles, before going on to examine and compare their war and peace policies.

The results of the content analysis are shown in Table 5. Aznar is slightly above average in the categories measuring openness to information: 0.18 points above average in lack of conceptual complexity and 0.18 points above average in self-confidence. His results in the motivation categories are disparate. His tendency to solve problems is around the average and his identification with groups is incredibly low at 0.27 points below average, but his distrust of other groups is 1.27 percent, i.e., 0.98 points above average. Consequently, the difference between his average score and the overall average is above the standard deviation (0.40) in this last category. Based on these results, Aznar can be classified as a suspicious leader, as with others in the database (Maskhadov, Umarov, Dudayev, Kadyrov, Uribe, Gaddafi and al-Assad), all of whom govern, or governed, countries immersed in armed conflicts.

Like Aznar, the results obtained by Zapatero in the openness to information categories are slightly above average: his lack of conceptual complexity is 0.16 points higher than the average, while his self-confidence is quite low at 0.49 points below average. In the motivation categories, neither does Zapatero show any identification with groups nor does he have a tendency to solve problems. As to the former, he obtains almost the same percentage as Aznar, while as to the latter, at 0.76 percent it is fairly high, i.e., 0.26 points above average, although not enough to classify him as a troubleshooter leader. As to the last category, his distrust of other groups is 0.23 points above average. According to these results, Zapatero can be classified as an administrator.

Before moving on to analyze the war (Table 6) and peace (Table 7) policies implemented by Aznar and Zapatero to tackle the Basque conflict from 1996 to 2011, it should be recalled that leaders with suspicious style (Aznar) should be more prone to prioritizing the former over the latter in accordance with leadership styles theory (Walker 1990; Burke and Greenstein 1991; Byman and Pollack 2001; Conway et al. 2001; Hermann 2003; Dyson 2006). 
Table 5. Results of Content Analysis: Aznar and Zapatero.

\begin{tabular}{|c|c|c|c|c|c|c|}
\hline & \multicolumn{2}{|c|}{ Database } & \multicolumn{2}{|c|}{ J.M. Aznar } & \multicolumn{2}{|c|}{ J. L. Rodríguez Zapatero } \\
\hline Number of interviews & \multicolumn{2}{|c|}{337} & \multicolumn{2}{|c|}{4} & \multicolumn{2}{|c|}{4} \\
\hline Number of words & \multicolumn{2}{|c|}{751,933} & \multicolumn{2}{|c|}{7412} & \multicolumn{2}{|c|}{9969} \\
\hline & Total Average & $\begin{array}{c}\text { Standard } \\
\text { Deviation }\end{array}$ & Average & $\begin{array}{c}\text { Leader's Average - } \\
\text { Total Average }\end{array}$ & Average & $\begin{array}{c}\text { Leader's Average - } \\
\text { Total Average }\end{array}$ \\
\hline Lack of conceptual complexity & 0.30 & 0.21 & 0.48 & 0.18 & 0.46 & 0.16 \\
\hline Self-confidence & 2.18 & 1.51 & 2.35 & 0.18 & 1.68 & -0.49 \\
\hline Tendency to solve problems & 0.51 & 0.33 & 0.54 & 0.04 & 0.77 & 0.26 \\
\hline Identification with group & 0.32 & 0.61 & 0.05 & -0.27 & 0.04 & -0.28 \\
\hline Distrust of other groups & 0.29 & 0.40 & 1.27 & $0.98 *$ & 0.52 & 0.23 \\
\hline Leadership Style & & & \multicolumn{2}{|c|}{ Suspicious } & \multicolumn{2}{|c|}{ Administrator } \\
\hline
\end{tabular}

* leader $\bar{X}-$ total $\bar{X}>\sigma$. Values in percentages. Source: Own elaboration. 
During his first years in office, Aznar took the same hard line (Barros et al. 2009) as his predecessor Felipe González (PSOE): continuing with the same dispersion policy as before, according to which ETA inmates were imprisoned far from home to prevent them from communicating among themselves (Zernova 2017); intense police action that not only affected the members of ETA, but also journalists, activists and political leaders in the organization's "orbit" (Linstroth 2002); and hindering judicial inquiries into the activities of the Antiterrorist Liberation Groups (GAL), a clandestine organization linked to the Spanish government, which had kidnapped and extra-judicially executed a number of ETA militants (González 1996, 3 August).

In this context-and with the decisive impact of the propaganda fiasco that had led to the murder of Blanco-some sectors of the Basque left-wing pro-independence movement questioned once again the armed struggle, defending instead a negotiated and exclusively political solution to the conflict. The example of the peace process in Northern Ireland (Mees 2001; Mansvelt Beck 2005; Whitfield 2014) and the combination of state repression and social disaffection with ETA's project led to the signing of the Lizarra Agreement, brokered by the terrorist organization, the Basque nationalist parties and the United Left (IU), ${ }^{18}$ whose purpose was to open a strategic action.

Emphasis was placed in this agreement on a political definition of the Basque conflict, and on a solution that was also political and that must be ratified by the citizenship, and in which the doors were not closed on any future scenario. On the basis of this unity of action, and heartened by ETA's truce, broad sectors of society—not only nationalists—considered that Euskadi found itself at the gates of a definitive solution to the problem of violence (Murua 2017, p. 16).

Following on the heels of the Lizarra Agreement, in September 1998 ETA declared a unilateral and indefinite ceasefire, in the hope that it would be reciprocated by the Spanish government. Two months later, Aznar announced at a public conference that he had "personally authorized contacts with intermediaries of the Basque Liberation Movement," with the aim of "substantiating the desire of the terrorist organization to take the necessary steps to open a peace process by means of a definitive end to the violence" (El País 2005). Although it was never admitted that there was any connection - the official discourse denied that political concessions would be made in exchange for dialogue-during the months that the ceasefire lasted there was a close up of prisoners in Basque jails (Esser and Bridges 2011).

Soon after this unprecedented move, however, things went back to square one. According to Ibarra and Ahedo (2004), the PP's general discourse during the ceasefire was based on three elements: that the truce was a trap in order to regroup; that it was the result of the nationalists having yielded to the pretentions of the terrorists (in reference to the Lizarra Agreement); and that the PNV had stepped up its separatist demands. Furthermore, in the words of the then Minister for Home Affairs Jaime Mayor Oreja, he had only agreed to come to the negotiating table to verify the surrender of ETA and not to discuss a political solution to the conflict (GEES 2014, 3 February), for which reason he had established the conditions for dialogue from the very start-which was contrary to the Lizarra Agreement.

After confirming that ETA was not prepared to surrender without obtaining some political payoff from the truce, the Spanish government did as it had done before the ceasefire: it stopped closing up prisoners, broke off the negotiations with ETA, filtered the names of some of the mediators and ordered the arrest of several of its leaders (Mees 2001; Ibarra and Ahedo 2004). Fourteen months after ETA's declaration of a unilateral ceasefire, and in the absence of any political progress, the negotiations were understood to have run aground (Barros et al. 2009). Thus, "ETA blamed the Spanish government for not creating a fair process for peace negotiations," after having failed to meet the basic requirements set out in the Lizarra Agreement, or to sign it for that matter (Linstroth 2002, p. 208). These explanations,

18 A Spanish electoral coalition including the Communist Party. 
however, did not convince some sectors of the Basque independence movement who withdrew their support for Herri Batasuna (HB), and others who created a new party Aralar which expressly condemned political violence (Ibarra and Ahedo 2004). Moreover, the Spanish government was not the only party that showed signs of ineptitude when managing the peace process and, even though ETA interrupted its armed actions, the ezker abertzalea ${ }^{19}$ continued with the kale borroka, the political vandalism against street furniture. Likewise, there were also reports confirming that the organization had made the most of the breathing space offered by the negotiations to rearm (Barros et al. 2009).

Subsequently, and in light of the peace of mind afforded by the absolute majority obtained in the 2000 elections and the favorable international climate after the 11-S attacks, Aznar took an even harder line with ETA through the passing of a new criminal legislation which had the support of the PSOE. For instance, as Zernova (2017) recalls, the Spanish parliament endorsed the bill to increase the number of days that those arrested for terrorist activities could be held in custody in solitary confinement, requested the judiciary that these types of offenders serve the full term, and reduced the scope of the so-called "prison benefits". By the same token, the legal definition of "terrorism" was broadened to include the kale borroka, collaboration with terrorist groups and the glorification of terrorism (Revenga Sánchez 2005). Lastly, Parliament also passed the Political Party Act, by virtue of which a number of Basque left-wing pro-independence parties were banned because of their links to ETA. All this was achieved with the explicit support of the EU, which drew up a list of "terrorists" including members and organizations of the Basque pro-independence left which had not taken up arms (Bourne 2003). These legal amendments resulted in a rise in the number of people arrested for terrorism-related crimes, many of whom had nothing to do with the armed conflict, as well as leading to the closure of media outlets and organizations of a political nature (Barros et al. 2009; Zernova 2017).

Concerning transitional justice, in 1999 the Spanish parliament, following a bill introduced by the Government, passed the Solidarity with the Victims of Terrorism Act, the first piece of legislation in this regard. It included the victims of "ETA, the GAL, jihadist violence and other armed organizations. The legislation, however, excludes other victims of the state, such as individuals killed or injured by members of the police forces and also victims of torture in police custody" (Álvarez Berastegi 2017, p. 13).

Zapatero's accession to power involved, among other things, a discursive turn with respect to the Spanish government's war and peace policies, which led to the withdrawal of the troops stationed in Iraq and a greater willingness to dialogue with ETA; unsurprisingly, different analyses debating on the possibility of a "second transition" in Spain were published at the time (Field 2009; Powell 2009). Given this opportunity, in 2004 the party Batasuna-which had already been banned-publically presented the Anoeta Declaration, a peace process model inspired yet again by the example of Northern Ireland (Alonso 2011). According to this declaration, after the ceasefire, ETA and Batasuna would start two different negotiation processes: the first, which would involve the armed organization, would discuss the technical aspects of a definitive end to the violence, i.e., disarming and prison policy; and the second, led by Batasuna, would broach the subject of an increase in self-rule or independence and the annexation of Navarre (Esser and Bridges 2011).

A year later, Zapatero took up the gauntlet, showing a readiness to resume contacts with ETA if the organization first laid down its arms (Woodworth 2007). During the following months, several secret meetings with intermediaries were held abroad (Eguiguren and Aizpeolea 2011) that led to an operative agreement with ETA (Murua 2017). Due to the good progress made in the negotiations, ETA sent a DVD to different Basque media outlets with a "video communique" declaring a ceasefire (Barros et al. 2009). Zapatero's initial reaction to this turn of events was to insist that time was needed to make sure that the organization was serious about abandoning the armed struggle, and in June 2006

19 Basque radical nationalist left. 
he announced that official—but secret—contacts would be established during the following weeks (Esser and Bridges 2011).

As before, the negotiations were marred by conflict. First and foremost, the PP accused the Government of breaking the "antiterrorist agreement" and discredited the work of the mediators for-allegedly-accepting the discourse of ETA (Alonso 2011). In parallel, the National Police continued to arrest members of the organization, which the pro-independence movement saw as an "obstacle to peace" (El País 2011), as well as prosecuting members of ETA. ${ }^{20}$ Lastly, "youth gangs of ETA sympathizers, presumably frustrated by the many postponements of the official negotiations, engaged in a revived kale borroka. Then, on October 24, ETA members carried out a robbery of more than 300 pistols from a French arms warehouse" (Esser and Bridges 2011, p. 65).

Besides the problems that the parties faced when respecting the ceasefire, there were also discrepancies about the negotiation strategy. While the Spanish government and the PNV wanted to address "first peace and then politics", ETA and the ezker abertzalea demanded "first politics and then peace" (Zulaika and Murua 2017, p. 340). Albeit undermined, the negotiations continued until 30 December 2006 when a bomb exploded at Terminal 4 of Barajas-Adolfo Suárez Airport (Madrid), killing two Ecuadorian immigrants. ETA claimed responsibility for the attack and the Spanish government promptly put an end to the dialogue (Barros et al. 2009).

The disappointing results of those negotiations, to which the PP had been strongly opposed, marked the following years of the government of Zapatero, who discarding his initial optimism began to deal with the conflict with a harder hand and greater mistrust. Thus, he did not revoke the Political Party Act, and during his term in office the political parties succeeding Batasuna were all banned and 50 activists in the "orbit" of ETA prosecuted as a result of Judicial Investigation 19/18. In the same vein, nor did he amend the defects of the Solidarity with the Victims of Terrorism Act to include those who had truly suffered during the conflict. "The critical point of divergence between Northern Ireland and the Basque Country is the structure of the peace process and the involvement of states in the transitional justice process" (Álvarez Berastegi 2017, p. 13).

Although there were several fatal attacks in the following years, ETA's operational capacity was drastically reduced, while the ezker abertzalea brought pressure to bear on the organization, urging it to declare a new and definitive ceasefire (Loyer 2015; Zulaika and Murua 2017). This came on 20 October 2011, a month before the PP had won the general elections. This process ended up being unilateral, thanks to the aforementioned grassroots pressure, Zapatero's lack of time and interest and the inflexibility of his successor Rajoy (Eguiguren and Aizpeolea 2011; Zernova 2017).

20 Undoubtedly the most notorious case during those years was that involving Iñaki de Juana Chaos. Serving time since 1987 for the murder of 25 people, by mid-2006 he was coming to the end of his sentence. However, in the middle of the truce, the National High Court brought proceedings against him for glorifying terrorism after writing and publishing two opinion pieces in the newspaper Gara. Considering this an attempt by the Spanish government to prevent his release (a "kidnapping", in the organization's terminology), de Juana Chaos began a hunger strike that unleashed a national controversy: the PP, the AVT and other conservative parties demanded that he be kept in prison and put pressure on Zapatero to prevent him from conceding to the demands of the secessionists and allowing him to be released. He was ultimately condemned in a case that set a legal precedent in Spain in the fight against terrorism (Arias Castaño 2007; García del Blanco 2007). 
Table 6. Aznar's (Suspicious) (1996-2004) and Zapatero's (Administrator) (2004-2011) War Policies.

\begin{tabular}{lcc}
\hline \multicolumn{1}{c}{ Policies } & Aznar & Zapatero \\
\hline Symbolic operations that are not intended to inflict casualties & 0 & 0 \\
Special criminal laws and national security programs & 1 & 1 \\
Banning political parties linked to the enemy & 1 & 1 \\
Collecting special taxes & 0 & 0 \\
Tactical deployment of the army and/or security forces & 0 & 0 \\
Declaration of a state of emergency or siege & 0 & 0 \\
Unlawful self-financing activities (drugs, arms or women trafficking) & 0 & 0 \\
Military operations & 0 & 0 \\
Forced recruitment and/or forced displacement & 0 & 0 \\
Illegal and extrajudicial executions and kidnapping & 0 & 0 \\
\hline
\end{tabular}

Source: own elaboration.

Table 7. Aznar's (Suspicious) (1996-2004) and Zapatero's (Administrator) (2004-2011) Peace Policies.

\begin{tabular}{lcc}
\hline \multicolumn{1}{c}{ Policies } & Aznar & Zapatero \\
\hline Proposing neutral mediators & 0 & 0 \\
Proposing dialogue or a peace process & 0 & 0 \\
Prisoner exchange & 0 & 0 \\
Ceasefire & 0 & 0 \\
Proposing agreements of a political, social or economic nature & 0 & 0 \\
Definitive end to the armed struggle & 0 & 0 \\
Disarmament & 0 & 0 \\
Compliance with transitional justice, reparation for victims and & 0 & 0 \\
guarantees for political participation & & \\
\hline
\end{tabular}

Source: own elaboration.

\section{Conclusions}

In this study, which dovetails with others (Rivas and Tarín 2017) that point to a link between the leadership of political leaders and the ways in which they manage armed conflicts, the methodological technique LTA was employed to evaluate the leadership styles of the former Spanish premiers José María Aznar-the conservative PP—and José Luis Rodríguez Zapatero—the progressive PSOE. This tried and tested discourse analysis tool has proven to be useful not only for explaining decision-making as regards foreign affairs (Hermann 2003; Dyson 2006, 2009a), but also for inquiring into war and peace policies. These two prime ministers were chosen because both supposedly defended antagonistic ideological stances during their terms in office, which is borne out by the fact that in the Spanish collective memory Aznar is recalled for his inflexibility with ETA and Zapatero for having championed dialogue. However, the research results point in a different direction:

1. Aznar possesses a "suspicious" leadership style, characterized by his "distrust of other groups". A "suspicious" leader has a much greater tendency to disregard peace and negotiation processes as ways of resolving armed conflicts. For his part, Zapatero is an "administrator" without any of the evaluated traits, but with tendency to solve problems and distrust towards other groups above average. Therefore, Aznar governed with a style more conducive to implementing war policies that Zapatero.

2. The war and peace policy analysis has yielded similar results in both cases which are consistent with the aforementioned leadership style (suspicious). Both Aznar and Zapatero endorsed and promoted the legal doctrine of "everybody belongs to ETA", suggesting an organic link between the armed organization and the mass media, social activists and the Basque left-wing pro-independence parties. At the same time, Aznar reached agreements with the PSOE to pass special laws against ETA—such as the so-called "antiterrorism agreement"—in addition to tightening the criminal code for offenses relating to Basque independence. Laws that Zapatero did not revoke, but maintained and enforced during his term in office. Lastly, there were many special 
police operations during the governments of both premiers, which also involved militarized security forces like the Civil Guard. In contrast, they were practically uncommitted to peace policies: Aznar tempered prison policies by regrouping ETA inmates in prisons located in the Basque Country, while Zapatero participated in a peace process negotiated with the armed organization which, as noted above, was interrupted for a number of reasons, some of which were beyond the control of the PSOE government.

3. In contrast with public opinion in Spain, the results obtained here suggest that-despite them having different leadership styles-there were no great differences between the war policies implemented by both prime ministers as regards the management of the Basque conflict. Although it has to be said that a few prison concessions cannot be compared with participating in a peace process, the Zapatero government maintained its war policies even during the truce. However, the latter does not mean that there are not differences between the peace policies implemented by both leaders: Aznar refused to start a peace process and the meeting with ETA in 1999 was just an exploratory meeting, not a dialogue process, while Zapatero opens a dialogue with this organization for the conflict resolution and he reached a secret agreement in 2005 which facilitated the truce of 2006-2007.

4. Nonetheless, the failure to resolve the Basque conflict peacefully during the period 1996-2011 was not only due to the Aznar and Zapatero governments' preference for war policies over peace policies. Certain factions of ETA that used the truces to rearm or were unwilling to make the necessary concessions should also shoulder their fair share of the blame.

Acknowledgments: We especially appreciate the collaboration of the researchers Asbel Bohigues, Nicolás Miranda and Sergio García-Rendón, as well as the comments and suggestions of the evaluators. José Manuel Rivas is a researcher funded by the University of Salamanca and Santander Bank.

Author Contributions: Adrián Tarín-Sanz conceived the idea of paper, reviewed the historical and biographical context and analyzed the war and peace policies; José Manuel Rivas designed the leadership styles classification, overviewed the theoretical framework, wrote the methodology and analyzed the leadership styles; both authors designed the war and peace policies and wrote the introduction and conclusions.

Conflicts of Interest: The authors declare no conflict of interest.

\section{References}

Acuerdo por las Libertades y Contra el Terrorismo (Agreement for Freedom and against Terrorism). December 8, 2000. Available online: https://web.archive.org/web/20060522001521/http:/ /www.mir.es/DGRIS/ Documentos_Informativos/Documentos_informativos/DocInf06.htm (accessed on 15 February 2018).

Alonso, Rogelio. 2011. The International Dimension of ETA's Terrorism and the Internationalization of the Conflict in the Basque Country. Democracy and Security 7: 184-204. [CrossRef]

Alonso, Sonia, Andrea Volkens, and Braulio Gómez. 2012. Análisis de contenido de textos políticos. Un enfoque cuantitativo. Madrid: CIS, vol. 47, ISBN 978-84-7476-590-8.

Álvarez Berastegi, Amaia. 2017. Transitional justice in settled democracies: Northern Ireland and the Basque Country in comparative perspective. Critical Studies on Terrorism. [CrossRef]

Amodia, José. 1996. Spain at the polls: The general election of 3 March 1996. West European Politics 19: 813-19. [CrossRef]

Arias Castaño, Abel. 2007. Amenazas, Enaltecimiento del Terrorismo y Libertad de Expresión: El caso De Juana Chaos. Revista para el Análisis del Derecho 4: 1-28.

Arnson, Cynthia J. 1999. Comparative Peace Processes in Latin America. Washington, DC: Woodrow Wilson Center Press, ISBN 978-0804735889.

Barros, Carlos P., Guglielmo M. Caporale, and Luis A. Gil-Alana. 2009. Basque terrorism: Police action, political measures and the influence of violence on the stock market in the Basque Country. Defence and Peace Economics 20: 287-301. [CrossRef]

Berelson, Bernard. 1952. Content Analysis in Communication Research. New York: Free Press.

Blondel, Jean, and Jean-Louis Thiébault. 2010. Political Leadership, Parties and Citizens. London and New York: Routledge. 
Bourne, Angela K. 2003. European integration and conflict resolution in the Basque Country, Northern Ireland and Cyprus. Perspectives on European Politics and Society 4: 391-415. [CrossRef]

Burke, John P., and Fred I. Greenstein. 1991. How Presidents Test Reality: Decisions on Vietnam, 1954 and 1965. New York: Russell Sage Foundation, ISBN 978-0871541765.

Burns, James M. 2010. Leadership. New York: Harper Collins, ISBN 978-0061965579.

Butler, Michael J. 2009. International Conflict Management. London: Routledge, ISBN 978-0415772303.

Byman, Daniel L., and Kenneth M. Pollack. 2001. Let Us Now Praise Great Men. Bringing the Statesman Back in. International Security 25: 107-46. [CrossRef]

Caminos-Marcet, José M., José I. Armentia-Vizuete, and María F. Marín-Murillo. 2013. Los diarios vascos frente al terrorismo (1990, 2000, 2008 y 2009). Análisis de los editoriales sobre los atentados mortales de ETA. Revista Latina de Comunicación Social 68: 1-26.

Canel, María J. 2012. Communicating strategically in the face of terrorism: The Spanish government's response to the 2004 Madrid bombing attacks. Public Relations Review 38: 214-22. [CrossRef]

Chari, Raj. 2008. The 2008 Spanish Election: A Balancing Game. West European Politics 31: 1069-77. [CrossRef]

Conway, Lucian G., Peter Suedfeld, and Philip E. Tetlock. 2001. Integrative Complexity and Political Decisions that Lead to War or Peace. In Peace, Conflict, and Violence: Peace Psychology for the 21st Century. Edited by Daniel J. Christie, Richard V. Wagner and Deborah Du N. Winter. New York: Prince Hall, pp. 66-75, ISBN 978-8189617554.

Conway, Lucian G., Peter Suedfeld, and Shannon M. Clements. 2003. Beyond the American Reaction: Integrative Complexity of Middle Eastern Leaders during the 9/11 Crisis. Psicología Politica 27: 93-104.

Conway, Lucian G., Laura J. Gornick, Houck Shannon, Kirsten H. Towgood, and Kathrene R. Conway. 2011. The Hidden Implications of Radical Group Rhetoric: Integrative Complexity and Terrorism. In The Relationship between Rhetoric and Terrorist Violence. Edited by Allison G. Smith. London: Routledge, pp. 71-81, ISBN 978-0415823609.

De la Calle, Luis, and Ignacio Sánchez-Cuenca. 2009. The End of Three Decades of Nationalist Rule: The 2009 Regional Elections in the Basque Country. South European Society and Politics 14: 211-26. [CrossRef]

Dyson, Stephen B. 2006. Personality and Foreign Policy: Tony Blair's Iraq Decisions. Foreign Policy Analysis 2 : 289-306. [CrossRef]

Dyson, Stephen B. 2009a. Cognitive Style and Foreign Policy: Margaret Thatcher's Black-and-White Thinking. International Political Science Review 30: 33-48. [CrossRef]

Dyson, Stephen B. 2009b. The Blair Identity. Leadership and Foreign Policy. Manchester: Manchester University Press, ISBN 978-0719079993.

Dyson, Stephen B. 2016. Gordon Brown, Alistair Darling, and the Great Financial Crisis: Leadership Traits and Policy Responses. British Politics, 1-16. [CrossRef]

Eguiguren, Jesús, and Luis Rodríguez Aizpeolea. 2011. ETA: Las claves de la paz: Confesiones de un negociador. Madrid: Aguilar, ISBN 978-8403012288.

El País. 2005. Aznar, en 1998: "He autorizado personalmente contactos". May 15. Available online: https: / / elpais.com/diario/2005/05/15/espana/1116108005_850215.html (accessed on 15 February 2018).

El País. 2011. Thierry: “No admitimos amenazas, si hay detenciones, ETA actuará". October 19. Available online: https:/ / politica.elpais.com/politica/2011/10/19/actualidad/1319041623_660301.html (accessed on 15 February 2018).

Elcock, Howard J. 2001. Political Leadership. Northampton: Edward Elgar Publishing, ISBN 978-1840640595.

Esser, James K., and Christine M. Bridges. 2011. Negotiating with Terrorists: The Case of the Basques and Spain. Peace and Conflict: Journal of Peace Psychology 17: 60-76. [CrossRef]

Field, Bonnie N. 2009. A 'Second Transition' in Spain? Policy, Institutions and Interparty Politics under Zapatero (2004-8). South European Society and Politics 14: 379-97. [CrossRef]

Fishman, Robert M. 2007. On being a Weberian (after Spain's 11-14 March): Notes on the continuing relevance of the methodological perspective proposed by Weber. In Max Weber's 'Objectivity' Reconsidered. Edited by Laurence Mcfalls. Toronto: University of Toronto Press, pp. 261-89, ISBN 0802092241.

García del Blanco, Victoria. 2007. Delitos de terrorismo, cumplimiento de pena y separación de poderes: el caso 'De Juana Chaos'. Icade 72: 225-57.

GEES. 2014. Lucha Contra ETA: Aznar, Zapatero, Rajoy. Grupo de Estudios Estratégicos. February 3. Available online: http:/ / www.gees.org/articulos/lucha-contra-eta-aznar-zapatero-rajoy (accessed on 15 February 2018). 
George, Alexander L. 1969. The Operational Code: A Neglected Approach to the Study of Political Leaders and Decision-making. International Studies Quarterly 23: 190-222. [CrossRef]

Gillespie, Richard. 2000. Political polarization in the Basque country. Regional \& Federal Studies 10: 112-24. [CrossRef]

Gómez-Fortes, Braulio, and Laura Cabeza-Pérez. 2013. Basque Regional Elections 2012: The Return of Nationalism under the Influence of the Economic Crisis. Regional \& Federal Studies 23: 495-505. [CrossRef]

González, Miguel. 1996. El Gobierno Niega a los Jueces Todos los Papeles del CESID Apelando a la Seguridad del Estado. El País, August 3. Available online: https:/ / elpais.com/diario/1996/08/03/espana/839023203_ 850215.html (accessed on 15 February 2018).

Greenstein, Fred I. 2009. The Presidential Difference: Leadership Style from FDR to Barack Obama. Princeton: Princeton University Press, ISBN 978-0691143835.

Helms, Ludger. 2012. Introduction: The Importance of Studying Political Leadership Comparatively. In Comparative Political Leadership. Coordinated by L. Helms; London: Palgrave Macmillan, pp. 1-24.

Hermann, Margaret G. 1986. Ingredients of Leadership. In Political Psychology. Edited by Margaret G. Hermann. San Francisco: Jossey-Bass Publishers, pp. 167-92.

Hermann, Margaret G. 2003. Assessing Leadership Style: A Trait Analysis. In The Psychological Assessment of Political Leaders: With Profiles of Saddam and Bill Clinton. Edited by Jerrold M. Post. Ann Arbor: The University of Michigan Press, pp. 178-212.

Hermann, Margaret G., and Thomas W. Milburn. 1977. A Psychological Examination of Political Leaders. New York: The Free Press, ISBN 978-0029145906.

Hermann, Margaret G., and Azamat Sakiev. 2011. Leadership, Terrorism, and the Use of Violence. Dynamics of Asymmetric Conflict 4: 126-34. [CrossRef]

Holsti, Ole R. 1977. Foreign policy decision makers viewed psychologically: "Cognitive process" approaches. In Thought and Action in Foreign Policy. Edited by G. Matthew Bonham and Michael J. Shapiro. Basel: Birkhäuser Verlag, pp. 120-43.

Ibarra, Pedro, and Igor Ahedo. 2004. The Political Systems of the Basque Country: Is a Non-Polarized Scenario Possible in the Future? Nationalism and Ethnic Politics 10: 355-86. [CrossRef]

Immelman, Aubrey. 2003. Personality in political psychology. In Handbook of Psychology: Vol. 5. Personality and Social Psychology. Edited by Irving B. Weiner. Volume edited by Theodore Millon and Melvin J. Lerner; Hoboken: Wiley, pp. 599-625.

Katz, Daniel. 1973. Patterns of Leadership. In Handbook of Political Psychology. Edited by Jeanne M. Knutson. San Francisco: Jossey-Bass, pp. 203-33.

Keating, Michael. 1996. The Spanish general elections of 3 March 1996. Regional E Federal Studies 6: 73-7. [CrossRef]

Keating, Michael, and Zoe Bray. 2006. Renegotiating Sovereignty: Basque Nationalism and the Rise and Fall of the Ibarretxe Plan. Ethnopolitics Formerly Global Review of Ethnopolitics 5: 347-64. [CrossRef]

Keller, Jonathan W., and Dennis M. Foster. 2016. Don't Tread on Me: Constraint-Challenging Presidents and Strategic Conflict Avoidance. Presidential Studies Quarterly 46: 808-27. [CrossRef]

Kernberg, Otto F. 1999. Ideología, conflicto y liderazgo en grupos y organizaciones. Barcelona: Paidós, ISBN 978-8449307089.

Korzenny, Felipe, and Stella Ting-Toomey. 1990. Communicating for Peace. Diplomacy and Negotiation. Newbury Park: Sage Publication.

Lago, Ignacio, and José R. Montero. 2006. The 2004 election in Spain: terrorism, accountability, and voting. Taiwan Journal of Democracy 2: 13-36.

Lasswell, Harold D. 1963. Psicopatología y política. Buenos Aires: Paidós.

Lebart, Ludovic, André Salem, and Mónica B. Bertaut. 2000. Análisis estadístico de textos. Lleida: Editorial Milenio.

Leonisio, Rafael. 2012. Parliament on the Centre-Right, Government on the Left: Explaining Basque Exceptionalism. Regional \& Federal Studies 22: 45-60. [CrossRef]

Levi, Ariel, and Philip E. Tetlock. 1980. A Cognitive Analysis of Japan's 1941 Decision for War. Journal of Conflict Resolution 24: 195-211. [CrossRef]

Lewin, Kurt, Ronald Lippitt, and Ralph K. White. 1939. Patterns of Aggressive Behavior in Experimentally Created Social Climates. Journal of Social Psychology 10: 271-99. [CrossRef] 
Linstroth, John Patrick. 2002. The Basque Conflict Globally Speaking: Material Culture, Media and Basque Identity in the Wider World. Oxford Development Studies 30: 205-22. [CrossRef]

Loyer, Barbara. 2015. Conflit at représentations du conflit au Pays Basque: la fin de ETA. Hérodote. Revue de éograohie et de Géopolitique 158: 16-38. [CrossRef]

Mansvelt Beck, Jan. 2005. Territory and Terror: Conflicting Nationalisms in the Basque Country. New York: Routledge, ISBN 978-0415348140.

Mares, David R., and David S. Palmer. 2012. Poder, instituciones y liderazgo en la paz y la guerra. Aprendizajes de Perú y Ecuador (1995-1998). Quito: FLACSO.

McAllister, Ian. 2007. The Personalization of Politics. In The Oxford Handbook of Political Behavior. Edited by Russell J. Dalton and Hans-Dieter Klingemann. New York: Oxford University Press, pp. 571-88.

Mees, Ludger. 2001. Between votes and bullets: Conflicting ethnic identities in the Basque Country. Ethnic and Racial Studies 24: 798-827. [CrossRef]

Mees, Ludger. 2015. Nationalist Politics at the Crossroads: The Basque Nationalist Party and the Challenge of Sovereignty (1998-2014). Nationalism and Ethnic Politics 21: 44-62. [CrossRef]

Murua, Imanol. 2017. Ending ETA's Armed Campaign: How and Why the Basque Armed Group Abandoned Violence. New York: Routledge.

Neustadt, Richard E. 1990. Presidential Power and the Modern Presidents. The Politics of Leadership from Roosevelt to Reagan. New York: The Free Press, ISBN 978-0029227961.

Pallarés, Francesc, Jordi Muñoz, and Alfredo Retortillo. 2006. Depolarization in the 2005 Autonomous Elections in the Basque Country: Towards a New Scenario for Peace? Regional \& Federal Studies 16: 465-79. [CrossRef]

Picarella, Lucia. 2009. Presidencialización y personalización en el Sistema Político Español, 1975-2008. Revista Enfoques: Ciencia Política y Administración Pública 7: 515-44.

Powell, Charles. 2009. A Second Transition, or More of the Same? Spanish Foreign Policy under Zapatero. South European Society and Politics 14: 519-36. [CrossRef]

Reinares, Fernando. 2014. ¡Matadlos! Quién estuvo detrás del 11-M y por qué se atentó en España. Barcelona: Galaxia Gutenberg.

Revenga Sánchez, Miguel. 2005. El tránsito hacia (y la lucha por) la democracia militante en España. Revista de Derecho Político 62: 11-31. [CrossRef]

Rivas, José M., and Adrián Tarín. 2017. Leadership Style and War and Peace Policies in the Context of Armed Conflict: The Case of Maskhadov and Umarov. Problems of Post-Communism 64: 1-19. [CrossRef]

Sánchez-Cuenca, Ignacio. 2009. ETA: del proceso de paz al regreso de la violencia. In La España de zapatero. Años de cambios (2004-2008). Edited by Anna Bosco and Ignacio Sánchez-Cuenca. Madrid: Pablo Iglesias, pp. 129-52. ISBN 978-84-95886-39-2.

Schafer, Mark, and Stephen G. Walker. 2006. Beliefs and Leadership in World Politics: Methods and Applications of Operational Code Analysis. Basingstoke: Palgrave Macmillan, ISBN 978-1403971821.

Schroder, Harold M. 1971. Conceptual Complexity and Personality Organization. In Personality Theory and Information Processing. Edited by Harold M. Schroder and Peter Suedfeld. New York: Ronald Press, pp. 240-73.

Torcal, Mariano, and Ignacio Lago. 2008. Electoral Coordination Strikes Again: The 2008 General Election in Spain. South European Society and Politics 13: 363-75. [CrossRef]

Walker, Stephen G. 1977. The Interface between Beliefs and Behavior: Henry Kissinger's Operational Code and the Vietnam War. Journal of Conflict Resolution 21: 129-68. [CrossRef]

Walker, Stephen G. 1990. The Evolution of Operational Code Analysis. Political Psychology 11: 403-18. [CrossRef]

Walker, Stephen G. 2011. Anticipating Attacks from the Operational Codes of Terrorist Groups. Dynamics of Asymmetric Conflict 4: 135-43. [CrossRef]

Waltz, Kenneth N. 1959. Man, the State and War. New York: Columbia University Press, ISBN 978-0231125376.

Whitfield, Teresa. 2014. Endgame for ETA. Elusive Peace in the Basque Country. London: Hurst.

Winter, David G. 1973. The Power Motive. New York: Free Press.

Winter, David G. 1991. A Motivational Model of Leadership: Predicting Long-term Management Success from TAT Measures of Power Motivation and Responsibility. Leadership Quarterly 2: 67-80. [CrossRef]

Winter, David G. 2003a. Measuring the motives of political actors at a distance. In The Psychological Assessment of Political Leaders: With Profiles of Saddam and Bill Clinton. Edited by Jerrold M. Post. Ann Arbor: The University of Michigan Press, pp. 153-77. 
Winter, David G. 2003b. Personality and political behavior. In Oxford handbook of political psychology. Edited by David O. Sears, Leonie Huddy and Robert Jervis. New York: Oxford University Press, pp. 110-45.

Winter, David G. 2011. Scoring Motive Imagery in Documents from Four Middle East Opposition Groups. In The Relationship between Rhetoric and Terrorist Violence. Edited by Allison G. Smith. London and New York: Routledge, pp. 60-70.

Woodworth, Paddy. 2007. The Spanish-Basque peace process: How to get things wrong. World Policy Journal 24: 65-73. [CrossRef]

Zernova, Margarita. 2017. Restorative justice in the Basque peace process: Some experiments and their lessons. Contemporary Justice Review 20: 363-91. [CrossRef]

Zulaika, Joseba, and Imanol Murua. 2017. How terrorism ends-And does not end: the Basque case. Critical Studies on Terrorism 10: 338-56. [CrossRef]

(C) 2018 by the authors. Licensee MDPI, Basel, Switzerland. This article is an open access article distributed under the terms and conditions of the Creative Commons Attribution (CC BY) license (http://creativecommons.org/licenses/by/4.0/). 